\title{
Nová sociální rizika a reformní trendy evropských sociálních států v reakci na ně̀
}

\author{
New Social Risks and Reform Trends of European Welfare States \\ in Reaction on These Risks
}

Lenka Klimplová

\begin{abstract}
The article presents a concept of new social risks developed by Esping-Andersen (1999), Taylor-Gooby (2004, 2005) and Armingeon, Bonoli (2006) and general reform trends of welfare states in reaction on these risks. The first part of the study concerns development and reform trends in Western European countries. The second part focuses on specificity of new social risks and reform trends in Central and Eastern European countries. The article concludes that general trends of welfare state reforms in response to emerging social risks in the countries of Western and of Central and Eastern Europe are alike. Emphasis is placed on strengthening of competitiveness and employability and on expanding of opportunities, for instance by lifelong education, by instruments of active employment policy, but also by socialization of care services to facilitate reconciling of work and family life. At the same time, trends of reinforcing the principle of self-responsibility for social welfare, the individualization of social risks and the involvement of other social actors (especially employers) in solving problems associated with new social risks have occurred.
\end{abstract}

KEY WORDS New social risks, welfare states, reforms, Western European countries, Central and Eastern European countries.

\section{Úvod}

Tato stat' vychází z funkcionalistického pojetí restrukturalizace sociálních států, které reformy sociálních politik národních států vysvětluje především rozsáhlými ekonomickými a demografickými procesy (Timonen 2003), jako např́klad globalizací, stárnutím populace, změnou struktur domácností, menším ekonomickým růstem či poklesem produktivity. Funkcionalistický př́stup se v podstatě odráží i v samotné definici tzv. nových sociálních rizik, jak byla pro účely této stati přjata od Armingeona a Bonoliho (2006). Podle zmíněných autorů lze nová sociální rizika definovat jako „situace, v nichž jedinci zažívají ztráty

Sociální studia. Fakulta sociálních studií Masarykovy univerzity, 1/2010. S. 23-43. ISSN 1214-813X.

1 Tato stat' vznikla s podporou Ministerstva školství mládeže a tělovýchovy ČR - NPV II. (Projekt 2D06009, Nová sociální rizika trhu práce a potřeby reformy jeho politické regulace po vstupu ČR do EU. Monitoring a evaluace potřeb.)

Autorka děkuje dvěma anonymním recenzentům a také editorovi čísla doc. PhDr. Jiřímu Winklerovi, $\mathrm{PhD}$. za jejich cenné připomínky k této stati i za rady pro budoucí publikační výstupy. 
blahobytu a jež se objevily jako di̊sledek socioekonomické transformace, která se uskutečnila v posledních třech čtyřech desetiletích a obecně je zahrnována pod titulek postindustrialismu“ (Armigeon, Bonoli 2006: 5). Podle citovaných autorů jde především o následující socioekonomické změny: masivní vstup žen na trh práce, rostoucí nestabilitu rodinných struktur, demografické změny (především stárnutí populace), deindustrializaci a posun $\mathrm{k}$ ekonomice služeb či nestandardní formy zaměstnávání (podrobněji viz např. Jaeger, Kvist 2003, Klimplová 2008).

Cílem této stati není analyzovat příčiny těchto socioekonomických procesů uvnitř národních států, které (vedle globalizace a europeanizace) vedou podle citovaných autorů (Esping-Andersen 1999, Pierson 2001, Jaeger, Kvist 2003, Taylor-Gooby 2004, Armingeon a Bonoli 2006, Bonoli 2007, Cerami 2008 atd.). k restrukturalizaci evropských sociálních států, ale poukázat na obecné reformni trendy, ke kterým vlivem těchto změn v zemích západní, ale i střední a východní Evropy dochází.

Pro vysvětlení restrukturalizace a reforem v jednotlivých evropských zemích je samozřejmě nutné kombinovat různé teoretické př́stupy (napřr. institucionalismus, ,path-dependency“, ${ }^{3}$ teorie mocenských zdrojů aj.), protože funkcionalistické pojetí samo o sobě - bez analýzy sociálních a politických aktérů, institucionálního rámce a fungování konkrétního národního sociálního státu jako takového - nedokáže vysvětlit rozdílnou strukturu reforem sociálních politik v jednotlivých evropských zemích. Ve stati jsou tyto vysvětlující proměnné (jako instituce, režim sociálního státu, zájmové struktury sociálních a politických aktérů, ale i načasování reforem aj.) částečně reflektovány, ale primárně jsou reformy sociálních států připisovány výše prezentovaným socioekonomickým změnám, a tedy chápany jako adaptace sociálních systémů na tzv. nová sociální rizika, která se v různých podobách (odlišná struktura a intenzita sociálních rizik v různých národních sociálních státech) postupně objevují ve všech evropských zemích. Právě v pozitivistickém nazírání a explanaci reforem sociálních států primárně za pomoci funkcionalistického př́stupu (kauzálního vztahu socioekonomické změny nová sociální rizika - reformy sociálních států) lze spatřovat limity této stati.

Přestože tato přehledová stat' není schopna detailně popsat a analyzovat všechny reformy ve všech zemích Evropské unie (a také to není jejím cílem), může být nápomocná k pochopení soudobých obecných reformních trendů $\mathrm{v}$ evropských sociálních státech i k pochopení drobných odlišností ve struktuře nových sociálních rizik a reformních tendencí v zemích střední a východní Evropy v komparaci se zeměmi západní Evropy. Může tak sloužit jako konceptuální východisko pro analýzy restrukturalizace sociálních politik v konkrétních národních státech EU, ovšem nutno dodat, že za předpokladu, že krom funkcionalistického pojetí využije k vysvětlení reforem i další diskutované teoretické prrístupy a jejich vysvětlující proměnné (Timonen 2003).

2 Ve smyslu změny systému produkce - od fordistického způsobu produkce, která je standardizovaná, fragmentovaná a formalizovaná, k post-fordistickému způsobu produkce s důrazem na flexibilní přizpůsobení se požadavkům individuálního zákazníka, diferenciaci a individualizaci výroby (viz podrobněji např. Schienstock et al. 1999, Wren 2001, Kubátová 2004, Klimplová 2010).

3 Z anglického ,path“ = dráha, cesta, způsob (řešení); ,dependency“ = závislost. 
Stat' má následující strukturu. V úvodní kapitole je blíže vymezen pojem nová sociální rizika a dále jsou diskutovány rozdíly mezi tzv. politikami starých a nových sociálních rizik. Další část je věnována reformám sociálních států v západních zemích a jejich adaptaci na diskutovaná nová sociální rizika. Následně se práce věnuje roli sociálních aktérů v procesu reforem sociálních států. Poslední část stati se zaměřuje na specifika nových sociálních rizik a na probíhající, respektive možné reformy sociálních států v zemích střední a východní Evropy. Závěr stati srovnává reformy zemí západní a střední a východní Evropy a shrnuje obecné reformní trendy evropských sociálních států v adaptaci na nová sociální rizika.

\section{Nová sociální rizika}

Nová sociální rizika byla v úvodu této stati definována jako situace, v nichž jedinci zažívají ztráty blahobytu a které se objevily jako důsledek socioekonomických změn, jakými jsou mj. deindustrializace a posun k ekonomice služeb, masivní vstup žen na trh práce, rostoucí nestabilita rodinných struktur či nestandardní formy zaměstnávání (Armigeon, Bonoli 2006). Taylor-Gooby $(2004 b, 2005)$ doplňuje další důležité procesy přinášející nová sociální rizika stárnutí populace a také privatizace sociálních služeb a opatření. Ta sama o sobě není rizikem, ale může způsobit nová rizika, „když se občané-konzumenti závaží k nevyhovujícím volbám a když je regulace standardů v systému privátního zaopatření neefektivni'“ (Taylor-Gooby 2004b: 4). Všechny tyto trendy - jak jednotlivě, tak v kombinaci jeden s druhým - pak změnily strukturu sociálních rizik v západních zemích (Bonoli 2007) a znamenaly vynoření nových rizikových sociálních skupin, které jednoduše nepatří ke klientele poválečných sociálních států, a proto zažívají výrazné ztráty blahobytu (Bonoli 2006). Těmito novými rizikovými skupinami jsou podle Bonoliho $(2006,2007)$ i Taylora-Goobyho (2004b) především mladí lidé, ženy a osoby nekvalifikované nebo s nizkou kvalifikací.

V návaznosti na Armingeona a Bonoliho (2006) a Taylora-Goobyho (2004a, 2005) můžeme nová sociální rizika vymezit následovně:

- ohrožení rovnováhy mezi pracovní kariérou a rodinnými povinnostmi (zejména péče o děti), jako důsledek mj. rozpadu tradičních rodin a změn v genderových rolích,

- ohrožení adekvátního zajištění péče o malé děti, závislé seniory a nemohoucí osoby v důsledku masivního vstupu žen na trh práce,

- ohrožení schopnosti získat adekvátní placené zaměstnání a mzdové zajištění v podmínkách nestandardních, flexibilních pracovních vztahů a kontraktů, především v důsledku nedostatku potřebné kvalifikace, znalostí a dovedností,

- riziko ztráty kvalifikace $\mathrm{v}$ důsledku rozvoje informačních technologií a zastarávání informací a ohrožení možnosti získání nové kvalifikace v prostředí mnohem flexibilnějších pracovních trhů,

- riziko zapříčiněné využíváním privátních sociálních systémů, která poskytují nejistou nebo neadekvátní podporu (penzi) nebo neuspokojivé služby,

- riziko nedostatečného pokrytí sociálním zabezpečením v období nezaměstnanosti, nemoci, invalidity či stáří v důsledku atypických (přerušovaných) pracovních kariér.

Tyto situace spolu nemusí nutně souviset a také se v konkrétních podmínkách jednotlivých národních sociálních států manifestují různě. Jsou zapř́ičené různými faktory, ale 
mají podle Bonoliho (2006) některé společné znaky. Za prvé, všechny je můžeme považovat za nová rizika v tom smyslu, že jsou typická pro soudobé postindustriální společnosti. V poválečných letech, označovaných jako „trente glorieuses“ (úžasné třicetiletí), v období plné zaměstnanosti mužů a udržitelného ekonomického růstu, byla tato rizika marginální, existovala-li vůbec. Za druhé, různá nová sociální rizika se koncentrují na ty samé skupiny jedinců, obvykle mladé lidi, rodiny s malými dětmi, pracující ženy, nekvalifikované a nízkokvalifikované osoby - tedy skupiny osob, které se navzájem překrývají. Nízkokvalifikovaná pracující žena s malým dítětem je tak vystavena dalším problémům kvůli kumulaci nevýhod, které ovlivňují její pozici. Za třetí, skupiny nejvíce ohrožené novými sociálními riziky nejsou obecně zabezpečeny sociálními systémy poválečných sociálních států. Tyto systémy se zaměřují na zaměstnanecké ,jádro“s kontrakty na plný úvazek a nepřerušovanou pracovní kariérou, především je cílem tohoto sociálního zabezpečení udržení př́ijmu muže-živitele. Výše identifikované skupiny, které jsou nejvíce ohroženy novými sociálními riziky, však nejsou těmito systémy téměř vůbec chráněny (Bonoli 2006).

\section{Politiky starých a nových sociálních rizik}

Politiky starých a nových sociálních rizik se od sebe navzájem liší, i když mají společný cíl - minimalizovat chudobu (Huber, Stephens 2006, Esping-Andersen 1999). Podívejme se nyní na tyto odlišnosti podrobněji.

Politiky starých sociálních rizik ${ }^{4}$ mohou být konceptualizovány jako „transfer-heavy“65 (Huber, Stephens 2006: 143), orientované na pokrývání rizik spojených se ztrátou schopnosti vydělávat $\mathrm{v}$ důsledku vysokého věku, nezaměstnanosti, nemoci či invalidity. Tyto politiky zahrnují především peněžní dávky pro staré lidi a pro pozůstalé (starobní a vdovské důchody), peněžní dávky a služby při pracovní neschopnosti a peněžní dávky v nezaměstnanosti (Bonoli 2007). Typickým (a modelovým) klientem „starého“ sociálního státu se zdá být muž ve výrobní dělnické profesi, který je živitelem rodiny. Rodina je pak chráněna skrze oprávnění muže-živitele.

Politiky nových sociálních rizik ${ }^{6}$ mohou být naopak konceptualizovány jako zaměřené na služby (,service-heavy“, 7 Huber, Stephens 2006: 143), orientované na zvyšování schopnosti jedinců vydělat si sami na sebe skrze pokračující vzdělávání, školení, rekvalifikace a socializaci pečovatelských služeb pro usnadnění harmonizace práce a rodinného života. Prioritou je tedy mobilizace populace s cílem posílit konkurenceschopnost a rozšiŕit př́ležitosti i pozměnit chování a uvědomění si vlastní odpovědnosti (Taylor-Gooby 2004b). Politiky nových sociálních rizik zahrnují především výdaje pro rodiny (peněžní dávky i služby), výdaje na aktivní politiky zaměstnanosti, na služby pro staré lidi a na sociální pomoc ve formě

$4 \quad$ Nazývané také jako industriální sociální politiky či poválečné sociální politiky (Bonoli 2007), nebo „staré“ sociální státy (Huber, Stephens 2006).

$5 \quad \mathrm{Z}$ anglického „transfer“ = převod, přenos; „heavy“ = s důrazem.

6 Nebo také postindustriální sociální politiky (Bonoli 2007), či „nové“ sociální státy (Huber, Stephens 2006)

$7 \quad$ Z anglického ,service“ = služba, servis; ,heavy“ = s důrazem. 
peněžních dávek i služeb (Bonoli 2007). Tyto politiky jsou obecně soustředěny na menší počet občanů a po kratší časovou dobu v jejich životě než politiky starých sociálních rizik, znamenají tedy i menší sociální výdaje (Taylor-Gooby 2005). Typický klient nového sociálního státu podle autorů neexistuje, ale lze téměř s jistotou říci, že jím není muž-živitel rodiny. Jedinci mohou být klienty „nového“ sociálního státu v různých životních fázích, např́íklad jako děti pracujících rodičů, mladiství př́i zácviku při vstupu na pracovní trh, dospělí v rekvalifikačních kurzech, pracující rodiče s malými dětmi či staří lidé potřebující pečovatelské služby (Huber, Stephens 2006).

Politiky nových sociálních rizik často nabízejí možnosti přeměnit slabé stránky v silné mobilizovat pracovní sílu, zvýšit produktivitu a posílit ekonomický růst a také vylepšit situaci znevýhodněných skupin (osamělých rodičů, nízko- a nekvalifikovaných pracovníků atd.) a snížit chudobu, to vše současně a s menšími finančními výdaji, než jsou výdaje na poskytování sociálních dávek. Navzdory těmto žádoucím cílům je však podle Taylora-Goobyho (2004d) pro vlády velmi obtížné reformovat své politiky tímto směrem, a to ze dvou důvodů. Za prvé, politiky nových sociálních rizik mají mnohem menší voličskou podporu než politiky starých sociálních rizik. Mladí lidé, nízkokvalifikovaní dělníci a ženy patří mezi skupiny s nedostatkem politického vlivu (Bonoli 2006), skupiny, které nejsou př́liš dobře organizovány odbory ani politickými stranami, jsou v mimořádném a především přechodném životním stádiu a navíc mají většinou silné rodinné vazby na „klíčové“ pracovníky (muže-živitele) mnohem více ohrožené starými než novými sociálními riziky. Stará sociální rizika se dotýkají dobře organizovaného jádra pracující populace a také výhod velkých zájmových skupin. Jak poznamenává Taylor-Gooby (2004d: 48): „Přeci jenom většina lidí očekává, že se stanou důchodci a má obavy ze ztráty př́ijmu z důvodu nemoci či invalidity.“

Druhým důvodem, proč je podle Taylora-Goobyho (2004d) pro vlády obtižné reformovat stávající politiky starých sociálních rizik směrem k těm novým, je to, že nová sociální rizika zahrnují sociální hodnoty dotýkající se rodinné a pracovní etiky a otázek materiálních zájmů. Zakořeněná př̀svědčení o jistých limitech státnich intervencí do fungování trhi̊ práce a rodinného života tak začínají být zpochybňována. Hodnotové otázky týkající se opatření starých sociálních rizik, jako např. invalidních či starobních penzí či nemocenské, jsou mnohem méně diskutována, protože legitimita těchto opatření má obecně širokou podporu i mezi ostatními evropskými sociálními státy. Z obou těchto důvodů jsou proto tolik žádoucí adaptace politik starých sociálních rizik na nová sociální rizika často velice obtížně politicky prosaditelné a proveditelné, nicméně jednotlivé národní státy si začínají uvědomovat, že tyto reformy jsou nezbytné. Následující kapitola popisuje některé reformní trendy.

\section{Reformní trendy západních sociálních států}

Analýzy různých autorů (např. Armingeon, Bonoli 2006, Bonoli 2006, 2007, Esping-Andersen 1999, Pierson 2001, Scharpf, Schmidt 2000a, 2000b, Taylor-Gooby 2004a, 2005) ukazují, že se politiky nových sociálních rizik v různých režimech sociálního státu (viz známá typologie Esping-Andersena 1990, 1999) liší. Jak ukazuje např́ílad Taylor-Gooby (2005), existující sociální politiky formovaly objevení se nových sociálních rizik v různých evropských zemích. Režimové rozdíly, nastavené ve většině př́ípadů v odpovědi na stará 
sociální rizika, jsou významnými faktory při nastavování schémat reagujících na nová sociální rizika v různých západoevropských zemích. ${ }^{8}$

Reformní procesy proto často zahrnují rozdílné strategie - oddělení klíčových sociálních aktérů (např. odborů) od podporujících koalic; hledání možností restrukturovat politiky podrytím součinnosti zájmových struktur tím, že některé skupiny rozvinou své zájmy jiným směrem; ${ }^{9}$ nebo rozvinutí dlouhého a detailního vyjednávání mezi všemi zainteresovanými sociálními aktéry, které je usnadněno tím, že jsou si všichni vědomi nedostatků ve stávajícím systému ${ }^{10}$ (Taylor-Gooby 2004d).

Bonoli $(2006,2007)$ přidává další důležitý faktor, který podle něj kromě režimových rozdílů „hraje klíčovou roli v určení schopnosti zemí adaptovat se na postindustriální svět" (Bonoli 2006: 14), a tím je načasováni. ${ }^{11}$ Rozdíly v „načasování“ rozhodujícího socioekonomického vývoje, jako je deindustrializace, změny v aspiracích žen či stárnutí populace, ovlivňují schopnost zemí reagovat na tyto změny i formování politik nových sociálních rizik. Například v severských zemích se expanze zaměstnávání v sektoru služeb a masivní vstup žen na trh práce vyvolávající potřebu harmonizace pracovního a rodinného života objevily již v sedmdesátých letech, tedy v období, kdy stárnutí populace ještě „,nenafouklo“ rozpočet určený pro penze a zdravotní péči. Naproti tomu kontinentální evropské země, jako např́klad Německo či Itálie, vstoupily do postindustriální éry o něco později (v devadesátých letech, nebo dokonce až na počátku nového tisíciletí) a současné problémy trhu práce a aspirace žen zapojit se na pracovní trh musí soupeřit se zachováním „starého“ sociálního státu (Bonoli 2006).

Zároveň však autoři (Taylor-Gooby 2005; Bonoli 2006, 2007) poukazují na to, že politiky nových sociálních rizik, které jednotlivé sociální státy rozvíjejí, nereflektují zcela konstantně charakteristiky existujících režimů politik starých sociálních rizik. Reformy nových sociálních rizik jsou sice všeobecně formovány skrze ,,path-dependency“ (Taylor-Gooby 2005: 46), jak bylo naznačeno výše, nicméně v některých ohledech se liší. Nástroje používané k uspokojení potřeb se totiž postupně mění. Například lze zaznamenat pokles příspěvků do schémat sociálního pojištění $\mathrm{k}$ financování státních výdajů v korporativistických zemích (například ve Francii) a naopak nárůst daňově financovaných schémat v tomto režimu sociálního státu (ibid.). Bonoli (2006) poukazuje na přejímání aspektů ze severského modelu i dalšími režimy sociálních států, především pak právě korporativistickým režimem. Jedná se především

8 Severské státy, kupř́ikladu, mají pevně ustavenou tradici pro pozitivní aktivaci a snaží se rozvinout politiky, které by napomohly zvládnout tlaky na rostoucí výdaje, ale zároveň udržet - co nejvíce je to možné - cíl „dlouhodobě fungujícího, rovnoprávného a univerzálního občanství“ (Taylor-Gooby 2005: 49). Korporativistické země čelí velkým problémům při transformaci, protože významné skupiny z řad sociálních partnerů jsou schopné využít své př́íležitosti a díky právu veta zablokovat reformy. Liberální Velká Británie šla nejdále v rozvoji tržně orientovaných politik, ale za cenu velké kritiky ze strany Evropské unie na adresu nedodržování doporučení EU týkajících se sociální ochrany a zabezpečení (ibid.).

9 Taylor-Gooby (2004) uvádí jako př́klad útlum státních a expanzi privátních penzijních schémat ve Velké Británii (Pierson 1994).

10 Např́klad penzijní reforma ve Švédsku (Timonen 2001, Taylor-Gooby 2005).

11 Důležitost načasování v politice teoreticky diskutuje např. Pierson (2004). 
o koncept flexicurity, ${ }^{12}$ včetně snižování ochrany pracovního místa a naopak zvyšování zajišstění zaměstnatelnosti osob, skrze aktivizaci a programy aktivni politiky zaměstnanosti nebo podporou celoživotního vzdělávání, ale také posilení politik pro podporu rovnosti mužů a žen na trhu práce a pro podporu harmonizace práce a rodinného života (EC, 2008) - tedy aspektů podle Bonoliho (2007) klíčových pro přežití sociálního státu v současném postindustriálním sociálním a ekonomickém prostředí.

Taylor-Gooby (2005: 47-49) výše popsanou změnu v prrístupu a nástrojích pro řešení současných sociálních problémů nazývá ,,novým paradigmatem $v$ sociální politice " a připisuje ho změně ekonomického paradigmatu v soudobých společnostech - posunu od neo-keynesiánského intervencionismu $\mathrm{k}$ pragmatickému monetarismu. Tento posun je podle zmíněného autora zapř́činěn třemi hlavními politickými změnami. Za prvé, kapacita vlád rozhodovat o ekonomické aktivitě skrze manipulaci se směnnými kurzy a úrokovými mírami je v současnosti limitována, a to ze dvou důvodu - jednak kvůli expanzi a globalizaci měnových trhů, které dovolují spekulantům profitovat manipulací s těmito kurzy, což má za následek destabilizaci hodnoty měn; a jednak kvůli operacím na vysoce konkurenčních mezinárodních trzích s mnoha produkty a službami, na nichž změna hodnoty měny, a tudíž i změna obchodních cen, smaže efekt jakékoliv politiky úrokových měr individuálního národního státu. Vlády už tak nejsou suverénními aktéry rozhodujícími o domácí ekonomice (podrobněji viz Scharpf, Schmidt 2000a).

Za druhé, defícitní financování už není nadále viděno jako správný motor pro pohánění ekonomického růstu a obranný mechanismus proti nezaměstnanosti v období ekonomické recese, pozornost politiků se naopak posunuje $\mathrm{k}$ metodám posilujicím flexibilitu a redukujicím překážky na trzích práce s cílem mobilizovat konkurenceschopnou pracovni sílu.

Za třetí, náklady na sociální státy jsou v globalizované ekonomice viděny primárně jako zátěž výrobniho sektoru a takové sociální politiky musí být ospravedlňovány jako sociální výdaje podporující především komparativní výhody (viz dále), spiše než sociální standardy jako takové (Taylor-Gooby 2005).

12 Termín ,flexicurity“ je chápán jako nový pohled na flexibilitu a ochranu na trhu práce a snaží se sjednotit tyto dvě základní potřeby. Flexicurity může být definována jako politická strategie podporující flexibilitu trhů práce, pracovních organizací i pracovních vztahů na jedné straně a vysokého stupně zajištění pracovního místa i př́ijmu na straně druhé. Vychází z přesvědčení, že globalizace a technologická změna prudce mění potřeby zaměstnanců i firem na pracovním trhu. Firmy jsou pod rostoucím tlakem adaptovat a mnohem rychleji rozvíjet své produkty a služby. Pokud chtějí na trhu práce uspět, musejí neustále přizpůsobovat své výrobní metody měnícím se požadavkům globalizovaného trhu a tomu musí přizpưsobovat i znalosti a dovednosti pracovni síly, což na firmy klade zvýšené nároky, co se týče zajišt'ování dalšiho vzděláváni svých zaměstnanců. Zaměstnanci jsou si naopak vědomi neustálých transformací podniků a setrvávání na jednom pracovním místě již pro ně není dostatečným zajištěním a může být ve své podstatě i kontraproduktivní. Aby zaměstnanci byli schopni plánovat své životy i kariéry, potřebují nový druh ochrany, která musí přesáhnout určitou pracovní pozici a zajistit bezpečný přechod do nového zaměstnání (EC, 2008). 
Tato změna ekonomického paradigmatu má podle Taylora-Goobyho (2005) značný vliv na evropské sociální státy a byla také významnou silou podporující rekomodifikaci, ${ }^{13}$ reka-

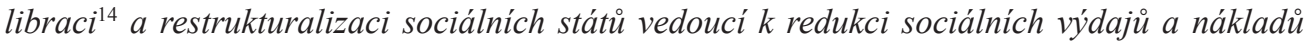
na pracovní sílu i posílení její flexibility (Pierson 2001). Zároveň znamenala posun odpovědnosti při uspokojování potřeb od státu k jednotlivcům a zaměstnavatelům (viz např. Mishra 1999) a také ospravedlnění omezení angažovanosti státu v naplňování některých potřeb svých občanů.

\section{Role sociálních partnerů při adaptaci sociálních států na nová sociální rizika}

Podle Taylora-Goobyho (2004c, 2005) mohou reformy sociálních států, reagující na nově se objevující sociální rizika, postupovat vpřed, navzdory tomu, že jsou nositelé nových rizik relativně slabou politickou silou, jak bylo zmíněno výše. Reformní proces závisí ve většině př́padů na programech preferovaných politickými aktéry, kteří jsou schopni uplatnit svůj vliv. Schopnost nalézt kompromis závisí na institucionálních podmínkách a na zájmech mobilizovaných na podporu konkrétního problému. Fakt, že nastavení sociálních států založené především na zájmech spojených se starými sociálními riziky lze modifikovat, je důkazem toho, že systémy, které byly někdy vnímány jako „,nehybné objekty“ (Taylor-Gooby 2004c: 233), souhlasí se změnami postavení sociálních partnerů. Tyto změny v rámci nastoleného sdružování se aktérů jsou mimořádně důležité pro rozvoj politik nových sociálních rizik. ${ }^{15}$ Podle tohoto autora se tak politiky nových sociálních rizik rozvinuly jako výsledek schopnosti vyjednávání a prosazení svých zájmů vlivnějšími politickými aktéry, než jsou sami nositelé nových sociálních rizik. Výsledkem jsou postupně se objevující reformy trhů práce vedené bud' požadavky na rozšíření negativní aktivace, s nároky na dávky podmíněnými aktivní snahou hledat zaměstnání a s politikami „make work pay“, které snižují poměr relativních sociálních dávek vzhledem ke mzdám (podporováno zaměstnavateli a pravicovými stranami), anebo požadavky na pozitivni aktivaci, která podporuje rozvoj dovedností a vzdělávání potřebný pro

13 Dekomodifikace se podle Esping-Andersena (1990) objevuje tehdy, když jsou služby poskytovány jako věc práv a člověk si může udržet svou existenci bez spoléhání se na trh práce. Rekomodifikace pak znamená opětovnou existenciální závislost na pracovním trhu, at' již formou zpřísnění kritérií nároku na dávky nebo jejich finanční redukcí (Pierson 2001).

14 Rekalibrací Pierson (2001) myslí reformy, které by pomohly učinit současný sociální stát konzistentnější se současnými cíli a požadavky na sociální zaopatření. Autor rozlišuje dva druhy rekalibrace: 1) racionalizace zahrnuje modifikaci programů v souladu s novými představami o tom, jak dosáhnout zamýšlených cílů (např. snahy korigovat programy evidentně „,nekompatibilní se stimuly“, Pierson 2001: 425, či př́pady překročení výdajů, které se projevují v souvislosti s měnícími se externími podmínkami a které následně významně ovlivňují fungování a funkci těchto programů); 2) aktualizace se týká snah adaptovat se na měnící se společenské požadavky a normy (změny ve struktuře domácností, životních drahách, povaze trhů práce či věkové struktuře společností).

15 Konkrétní prríklady těchto změn v pozicích sociálních aktérů v režimově odlišných zemích uvádí Taylor-Gooby (2004: 234-235). 
(re)integraci na pracovní trh (podporováno sociálně demokratickými stranami). ${ }^{16} \mathrm{~V}$ obou prístupech je důraz kladen na mobilizaci pracovní síly za pomoci její aktivace, model reforem (př́klon k negativní či pozitivní aktivaci) je však očividně ovlivněn politikami starých sociálních rizik, které komponují režim toho kterého národního sociálního státu.

Sociální partneři, zejména pak zaměstnavatelé, hrají důležitou roli při tvorbě politických koncepcí reagujících na nově se objevující rizika, stejně tak jsou důležité i „modernizující koalice" mezi politickými stranami a zájmovými skupiny sociálních partnerů (Taylor-Gooby 2005: 82). Vzhledem k tomu, že novými sociálními riziky nejvíce ohrožené skupiny neparticipují na vytváření nových reforem, výstupy těchto reforem naplňují zájmy vlivných sociálních aktérů (zaměstnavatelů, koalic politických aktérů a zájmových skupin apod.) v mnohem větši míře, než tomu bylo v prrípadě starých sociálních rizik (Taylor-Gooby 2005, Armingeon, Bonoli 2006).

\section{Nová sociální rizika v zemích střední a východní Evropy}

Až dosud jsme sociální rizika a adaptaci sociálních států na ně diskutovali z perspektivy západních zemí, kde sociální stát ve své současné podobě existuje již několik desetiletí. V postkomunistických zemích střední a východní Evropy je trend posunu od industrialismu k postindustrialismu navíc propojen se změnami spojenými se socio-ekonomickou transformací při přechodu od centrálně plánované ekonomiky $\mathrm{k}$ tržní ekonomice a kromě výše prezentovaných nových sociálních rizik identifikovaných $\mathrm{v}$ západních zemích se musí tyto společnosti a jejich sociální státy potýkat i s riziky, která jsou kompletně rozdílná od těch, se kterými se tyto země musely vyrovnávat před rokem 1989 (těmi byla především rizika spojená s nemožností najít spotřební zboží v důsledku „ekonomie nedostatku“ a nekvalitní sociální služby). Proto to, co bývá v zemích západní Evropy označováno za „stará“ sociální rizika, může být, spolu s těmi nově se objevujícími, současnými klíčovými výzvami pro sociální státy zemí střední a východní Evropy. Nejistý př́stup k penzím, zdravotní péči, zaměstnání, nezbytnému př́ijmu, rodinným politikám i vzdělávacím př́ležitostem, to vše přispívá $\mathrm{k}$ objevení se nových forem sociální exkluze a chudoby v těchto postkomunistických zemích (Cerami 2008). ${ }^{17}$

16 Tyto dvě rozdílné tendence $\mathrm{v}$ soudobých reformách politiky zaměstnanosti, obě však zacílené na aktivaci pracovní síly, popisuje Ellison (2006) jako „work first“ přístup a „human capital“ přistup. Přistup ,,work first“ (z angl. ,work“ = práce, zaměstnání; „first“ = první; tedy na prvním místě zaměstnání) se zaměřuje na rychlý přesun nezaměstnaných do zaměstnání. Určité množství vzdělávání a tréninkové asistence může být poskytováno (často však spíše privátními agenturami než veřejnými službami zaměstnanosti), důraz je kladen především přímo na intenzivní poradenství a hledání zaměstnání, často podepřené systémem penalizací pro ty, kteří nevyhoví systémovým a programovým požadavkům. Př́stup , human capital“ (lidský kapitál) rozvíjí politiky, které zdůrazňují důležitost vzdělání a tréninku jako nejlepších prostředků k ochraně zaměstnání a udržitelného přechodu do zaměstnání. Nejde jen o přípravu účastníků pro konkrétní pracovní místo, ale růstem určité úrovně lidského kapitálu rozšiřuje recipientům sociálních dávek škálu možností pro přijetí do zaměstnaností v budoucnosti.

17 Barr (2005) vymezuje soubor sociálních problémů, se kterými se země střední a východní Evropy musely (a ve většině případů stále musejí) po pádu komunismu potýkat a které nasměrovaly 
Za nejvýznamnější sociální trendy spojené s přechodem k postindustriální, na znalostech založené ekonomice v zemích střední a východní Evropy považuje Cerami (2008):

- změny ve struktuře pracovních sil

- růst počtu nezaměstnaných $\mathrm{v}$ důsledku propouštění zaměstnanců z řady státem vlastněných podniků - např́klad v České republice došlo $\mathrm{k}$ výraznějšímu nárůstu počtu nezaměstnaných až koncem 90 . let (viz Tabulku 1), ${ }^{18}$ v roce 1993 bylo v ČR 220 tisíc nezaměstnaných, nejvíce nezaměstnaných bylo dle Českého statistického úřadu $\mathrm{v}$ roce 2000 - 454,5 tisíce, poté došlo opět $\mathrm{k}$ postupnému poklesu počtu nezaměstnaných, v roce 2007 bylo nezaměstnaných 276,3 tisíc osob (ČSÚ 2008);

Tabulka 1: Vývoj počtu nezaměstnaných v České republice, 1993-2007 (v tisících)

\begin{tabular}{|l|c|c|c|c|c|c|c|c|}
\hline & $\mathbf{1 9 9 3}$ & $\mathbf{1 9 9 4}$ & $\mathbf{1 9 9 5}$ & $\mathbf{1 9 9 6}$ & $\mathbf{1 9 9 7}$ & $\mathbf{1 9 9 8}$ & $\mathbf{1 9 9 9}$ & $\mathbf{2 0 0 0}$ \\
\hline Celkem & 220,0 & 221,2 & 208,1 & 201,5 & 248,3 & 335,7 & 454,1 & 454,5 \\
\hline & $\mathbf{2 0 0 1}$ & $\mathbf{2 0 0 2}$ & $\mathbf{2 0 0 3}$ & $\mathbf{2 0 0 4}$ & $\mathbf{2 0 0 5}$ & $\mathbf{2 0 0 6}$ & $\mathbf{2 0 0 7}$ & \\
\hline Celkem & 418,3 & 374,1 & 399,1 & 425,9 & 410,2 & 371,3 & 276,3 & \\
\hline
\end{tabular}

Zdroj: ČSÚ, 2008b, tabulka Nezaměstnanost dle oblastí a krajů, $\check{C} R$.

- růst zaměstnanosti (a sebezaměstnávání) v privátním sektoru v důsledku privatizace centrálně plánované ekonomiky - např. počet „pracujících na vlastní účet“ v České republice vzrostl dle údajů Českého statistického úr̆adu mezi roky 1993 a 2007 o 273,5 tisíc (ČSÚ 2008);

- značný pokles počtu lidí pracujících v zemědělství a průmyslovém sektoru, pouze částečně pokrytý nárůstem počtu osob zaměstnaných ve službách - v České republice poklesl počet zaměstnaných v zemědělství (zemědělství, myslivost, lesnictví, rybolov a související činnosti) mezi roky 1993 a 2007 o více než polovinu, z 375 tisíc na 176,3 tisíc osob, počet zaměstnaných v průmyslu poklesl za stejné období o 113,7 tisíc osob, na druhou stranu došlo k nárůstu počtu osob zaměstnaných ve službách o 360,3 tisíce - z 2405,5 tisíc v roce 1993 na 2765,8 tisíc v roce 2007 (viz tabulky 2, 3 a 4, ČSÚ 2008);

- formování nové manažerské elity (trrídy), vytvořené z větší části z předchozích administrativních pracovníků a technokratů;

sociální reformy, následovně: klesající zaměstnanost a rostoucí nezaměstnanost, rostoucí chudoba, neefektivní zacílení sociálních dávek, zhoršující se zdraví, nevhodné vzdělávací výstupy.

18 Analýza vývoje nezaměstnanosti v letech 1991 - 2000 s detailním popisem příčin nárůstu nezaměstnanosti až koncem 90. let viz Klimplová (2001). 
Tabulka 2: Zaměstnání v národním hospodářství (Česká republika, 1993-2007) zemědělství (v tis.)

\begin{tabular}{|c|c|c|c|c|c|c|c|c|}
\hline & 1993 & 1994 & 1995 & 1996 & 1997 & 1998 & 1999 & 2000 \\
\hline $\begin{array}{l}\text { Zemědělství, myslivost } \\
\text { a související činnosti }\end{array}$ & 321,6 & 284,6 & 264,1 & 250,4 & 229,8 & 217,8 & 200,7 & 190,2 \\
\hline $\begin{array}{l}\text { Lesnictví, rybolov, chov ryb } \\
\text { a souv. činnosti }\end{array}$ & 53,4 & 53,3 & 61,6 & 54,9 & 54,6 & 49,2 & 46,6 & 50,5 \\
\hline \multirow[t]{2}{*}{ CELKEM ZEMĚDĚLSTVÍ } & 375,0 & 337,9 & 325,8 & 305,4 & 284,4 & 266,9 & 247,3 & 240,7 \\
\hline & 2001 & 2002 & 2003 & 2004 & 2005 & 2006 & 2007 & \\
\hline $\begin{array}{l}\text { Zemědělství, myslivost } \\
\text { a související činnosti }\end{array}$ & 177,8 & 184,2 & 172,1 & 162,9 & 150,7 & 144,3 & 140,8 & \\
\hline $\begin{array}{l}\text { Lesnictví, rybolov, chov ryb } \\
\text { a souv. činnosti }\end{array}$ & 47,4 & 43,7 & 41,1 & 39,4 & 38,7 & 37,4 & 35,5 & \\
\hline CELKEM ZEMĚDĚLSTVÍ & 225,1 & 227,9 & 213,1 & 202,3 & 189,4 & 181,7 & 176,3 & \\
\hline
\end{tabular}

Zdroj: ČSÚ, 2008b, tabulka Odvětví zaměstnaných v NH, ČR.

Tabulka 3: Zaměstnání v národním hospodářství (Česká republika, 1993-2007) prümysl (v tis.)

\begin{tabular}{|c|c|c|c|c|c|c|c|c|}
\hline & 1993 & 1994 & 1995 & 1996 & 1997 & 1998 & 1999 & 2000 \\
\hline Těžba nerostných surovin & 125,7 & 99,3 & 97,3 & 90,1 & 88,9 & 85,8 & 77,2 & 70,4 \\
\hline Zpracovatelský průmysl & 1444,4 & 1429,1 & 1421,6 & 1407,4 & 1369,5 & 1340,8 & 1307,8 & 1281,5 \\
\hline $\begin{array}{l}\text { Výroba a rozvod elektřiny, } \\
\text { plynu a vody }\end{array}$ & 98,9 & 98,2 & 102,0 & 100,2 & 92,0 & 93,3 & 83,7 & 77,5 \\
\hline Stavebnictví & 423,9 & 451,7 & 455,4 & 467,5 & 480,9 & 472,0 & 443,2 & 439,0 \\
\hline \multirow[t]{2}{*}{ CELKEM PRŮMYSL } & 2093,0 & 2078,3 & 2076,3 & 2065,1 & 2031,1 & 1992,0 & 1911,9 & 1868,4 \\
\hline & 2001 & 2002 & 2003 & 2004 & 2005 & 2006 & 2007 & \\
\hline Těžba nerostných surovin & 67,1 & 61,1 & 53,3 & 58,6 & 49,3 & 54,9 & 54,2 & \\
\hline Zpracovatelský průmysl & 1310,4 & 1318,2 & 1294,3 & 1274,2 & 1296,1 & 1361,5 & 1405,5 & \\
\hline $\begin{array}{l}\text { Výroba a rozvod elektřiny, } \\
\text { plynu a vody }\end{array}$ & 87,3 & 83,8 & 77,1 & 76,2 & 76,6 & 76,7 & 72,7 & \\
\hline Stavebnictví & 427,7 & 425,2 & 438,7 & 435,6 & 458,5 & 436,3 & 446,8 & \\
\hline CELKEM PRŮMYSL & 1892,6 & 1888,3 & 1863,4 & 1844,6 & 1880,5 & 1929,4 & 1979,3 & \\
\hline
\end{tabular}

Zdroj: ČSÚ, 2008b, tabulka Odvětví zaměstnaných v NH, ČR. 
Tabulka 4: Zaměstnání v národním hospodářství (Česká republika, 1993-2007) služby (v tis.)

\begin{tabular}{|c|c|c|c|c|c|c|c|c|}
\hline & 1993 & 1994 & 1995 & 1996 & 1997 & 1998 & 1999 & 2000 \\
\hline $\begin{array}{l}\text { Obchod, opr. motor. vozidel } \\
\text { a spotřebního zboží }\end{array}$ & 510,3 & 589,1 & 618,6 & 639,6 & 658,7 & 645,5 & 640,6 & 612,9 \\
\hline Ubytování a stravování & 148,9 & 149,4 & 153,9 & 155,6 & 166,2 & 169,2 & 157,4 & 156,3 \\
\hline Doprava, skladování a spoje & 388,1 & 370,3 & 381,8 & 388,2 & 381,6 & 378,1 & 371,0 & 373,2 \\
\hline Finanční zprostředkování & 68,1 & 81,3 & 91,5 & 94,8 & 96,6 & 99,7 & 98,8 & 99,6 \\
\hline $\begin{array}{l}\text { Nemovitosti a pronájem, } \\
\text { podnikatelské činnosti }\end{array}$ & 219,6 & 241,6 & 245,4 & 256,1 & 251,9 & 248,4 & 256,5 & 266,0 \\
\hline $\begin{array}{l}\text { Veřejná správa a obrana, } \\
\text { povinné soc. zabezp. }\end{array}$ & 308,4 & 322,4 & 302,3 & 310,6 & 320,6 & 322,8 & 336,5 & 342,9 \\
\hline Vzdělávání & 315,0 & 310,6 & 309,2 & 311,8 & 306,4 & 289,0 & 286,7 & 298,9 \\
\hline $\begin{array}{l}\text { Zdravotní a sociální péče, } \\
\text { veterin. činnosti }\end{array}$ & 282,1 & 279,0 & 283,0 & 273,0 & 272,4 & 267,7 & 276,6 & 290,7 \\
\hline $\begin{array}{l}\text { Ostatní veřejné, sociální } \\
\text { a osobní služby }\end{array}$ & 162,9 & 162,8 & 170,4 & 166,2 & 161,3 & 182,5 & 176,1 & 175,8 \\
\hline Činnosti domácností & 1,1 & 0,5 & 1,3 & 2,0 & 1,2 & 1,3 & 1,8 & 1,7 \\
\hline $\begin{array}{l}\text { Exteritoriální organizace } \\
\text { a instituce }\end{array}$ & 1,1 & 1,4 & 0,8 & 1,6 & 1,8 & 1,5 & 1,5 & 2,0 \\
\hline \multirow[t]{2}{*}{ CELKEM SLUŽBY } & 2405,5 & 2508,4 & 2558,1 & 2599,4 & 2618,7 & 2605,9 & 2603,5 & 2620,1 \\
\hline & 2001 & 2002 & 2003 & 2004 & 2005 & 2006 & 2007 & \\
\hline $\begin{array}{l}\text { Obchod, opr. motor. vozidel } \\
\text { a spotřebního zboží }\end{array}$ & 604,9 & 619,8 & 627,8 & 630,9 & 614,8 & 613,6 & 613,1 & \\
\hline Ubytování a stravování & 158,7 & 170,5 & 170,7 & 174,8 & 181,7 & 187,0 & 181,5 & \\
\hline Doprava, skladování a spoje & 362,6 & 367,6 & 358,8 & 364,0 & 359,7 & 361,0 & 363,8 & \\
\hline Finanční zprostředkování & 101,4 & 95,2 & 96,3 & 93,6 & 96,5 & 92,2 & 101,7 & \\
\hline $\begin{array}{l}\text { Nemovitosti a pronájem, } \\
\text { podnikatelské činnosti }\end{array}$ & 256,0 & 269,1 & 284,9 & 281,5 & 288,3 & 321,3 & 353,0 & \\
\hline $\begin{array}{l}\text { Veřejná správa a obrana, } \\
\text { povinné soc. zabezp. }\end{array}$ & 339,3 & 325,7 & 331,9 & 322,5 & 333,2 & 325,6 & 326,4 & \\
\hline Vzdělávání & 300,0 & 309,1 & 287,8 & 279,0 & 296,6 & 287,6 & 290,1 & \\
\hline $\begin{array}{l}\text { Zdravotní a sociální péče, } \\
\text { veterin. činnosti }\end{array}$ & 304,3 & 304,2 & 306,9 & 323,6 & 328,1 & 329,9 & 338,2 & \\
\hline $\begin{array}{l}\text { Ostatní veřejné, sociální } \\
\text { a osobní služby }\end{array}$ & 178,2 & 179,4 & 185,1 & 184,4 & 189,8 & 193,0 & 194,3 & \\
\hline Činnosti domácností & 1,3 & 3,3 & 4,3 & 3,2 & 3,2 & 3,5 & 2,7 & \\
\hline $\begin{array}{l}\text { Exteritoriální organizace } \\
\text { a instituce }\end{array}$ & 0,8 & 1,1 & 0,9 & 1,0 & 0,7 & 1,5 & 1,0 & \\
\hline CELKEM SLUŽBY & 2607,4 & 2645,0 & 2655,4 & 2658,5 & 2692,6 & 2716,0 & 2765,8 & \\
\hline
\end{tabular}

Zdroj: ČSÚ, 2008b, tabulka Odvětví zaměstnaných v NH, ČR. 
- změny ve struktuře zaměstnaneckých vztahi̊

- opuštění celoživotního zaměstnaneckého statusu neboli od trvalého pracovního poměru k flexibilnějším pracovním smlouvám - během komunismu měli zaměstnanci jistotu zaměstnání po celou svou pracovní kariéru, pracovní smlouvy byly ve většině př́ípadů na dobu neurčitou, lidé zůstávali v jednom zaměstnání od ukončení školy až do důchodu; s přechodem k tržní ekonomice se začínají mnohem častěji objevovat flexibilnější typy pracovních smluv (jako např. smlouvy na dobu určitou, částečné úvazky, smlouvy na př́íležitostnou práci bez udání pracovní doby, smlouvy pro pracovníky dočasně najímané skrze zprostředkovatelské agentury, smlouvy s osobami samostatně výdělečně činnými atp.), znamená to větší flexibilitu pro zaměstnavatele, ale menši jistotu zaměstnání pro zaměstnance;

- změna vztahu mezi pracovní výkonností a odměnou za práci (plat závisí na výkonnosti a produktivitě) - v období komunismu byly mzdy centrálně plánované, nezávislé na produktivitě práce; $v$ tržní ekonomice je mnohem častěji výše mezd determinována výkonností a produktivitou toho kterého zaměstnance (Barr 2005);

- nárůst mzdových rozdílů - významně souvisí s předchozím bodem, v centrálně plánované ekonomice byly centrálně plánované mzdy spíše nižší, ale doplněné řadou subvencí, mzdová diferenciace byla nízká, všichni měli (skoro) stejně; s přechodem $\mathrm{k}$ tržní ekonomice došlo $\mathrm{k}$ rozšiřování př́ijmové distribuce $\mathrm{v}$ důsledku toho, že pracovníci začali být odměňováni na základě své výkonnosti a produktivity, vzdělání a pracovní zkušenosti začaly výrazně ovlivňovat mzdy, navíc státní subvence spojené se zaměstnáním ve státem vlastněných podnicích zmizely (např. Ringold 2005); Giniho koeficient, ukazující př́ijmovou nerovnost, ${ }^{19}$ tak pro Českou republiku lehce narůstá - v polovině 90 . let měl tento koeficient hodnotu 0,25, v roce 2000 0,26 a v roce 2005 hodnotu 0,27 (OECD 2008 - indikátor CO7); ${ }^{20}$ podíváme-li se na poměr př́imů horního decilu a spodního decilu, zjistíme, že se mezi polovinou 90. let a rokem 2005 zvýšil z 2,8 na 3,2, tzn., že v roce 2005 měly osoby v horním decilu 3,2 vyšší př́ijem než osoby v nejnižším decilu (ibid.).

- demografické změny a změny v kompozici rodin a domácností

- pokles míry fertility - míra fertility v České republice v roce 1970 byla 1,91, $\mathrm{v}$ roce 19951,83 a v roce 2006 pouhých 1,33 (OECD 2008 - indikátor SF4), to je hluboko pod tzv. replacement mírou, která činí 2,1 (Malmberg 2006), tzn., že se populace postupně zmenšuje a rostoucí průměrná délka dožití naklání demografickou rovnováhu od mladých ke starým, s potenciálně významnými dopady na životní úroveň;

190 znamená „perfektní“ rovnost, všichni mají stejný př́ijem, 1 znamená „perfektní“ nerovnost, veškerý př́jem je vyděláván jednou osobou (Ringold 2005, OECD 2008).

20 Přes tento nárůst patří Česká republika mezi země OECD s nejnižším Giniho koeficientem (OECD 2008 - indikátor CO7). 
- stárnutí populace - souvisí významně s předchozím bodem, průměrný věk obyvatelstva v ČR se zvýšil z 38,2 roků v roce 1998 na 40,3 roku v roce 2007, index stáŕí (podíl počtu osob ve věku 65 let a více na počet osob ve věku 0 až 14 let, v procentech) se ve stejném období zvýšil z 80,6 na 102,4 (ČSÚ 2008);

- méně sňatků, větší rozvodovost - hrubá míra sňatečnosti (počet sňatků na 1000 obyvatel středního stavu) poklesla v Č́R z 8,8 v roce 1990 na 5,1 v roce 2001; rozvodový index (počet rozvodů na 100 sňatků v daném roce) ve stejném období vzrostl z 35,2 na 60,3 , absolutní počty rozvodů se po celá 90 . léta a na počátku tohoto století pohybovaly kolem 30 tisíc rozvodů za rok, ${ }^{21}$ rozvodový index narostl především kvůli poklesu sňatečnosti (ČSÚ 2002);

- rostoucí chudoba především jednočlenných domácností, osamocených rodičů $\mathrm{s}$ dětmi, domácností s třemi a více dětmi, domácností s nezaměstnaným, zaměstnaným na částečný úvazek nebo na atypické úvazky, domácností Romů (viz např̀. Ringold 2005, Cerami 2008);

- individualizace odpovédnosti a zpeněžněni ekonomických a sociálních vztahů podle Ceramiho (2008) klíčový aspekt sociální změny objevující se v postkomunistických zemích. Během komunismu byla veřejná odpovědnost vedoucím principem regulujícím veškerý sociální život. Komunita, a ne jedinci, byla vlastníkem sociálních práv (Cerami 2006). Plná zaměstnanost byla za komunismu pravidlem (každý občan neměl jen právo, ale i povinnost pracovat), zdroje byly veřejné a alokovány centrálně, ne skrze trhy. Ceny byly určovány administrativně, s velkým množstvím subvencí od státem vlastněných podniků (bydlení, doprava, dovolené apod.) a univerzálních sociálních transferů v peněžní i nepeněžní formě (Barr 2005). S nástupem tržní ekonomiky se situace změnila. Na jedné straně individualizace sociálních práv dala lidem větší moc stát se zodpovědnými za svoji budoucnost, na druhé straně však ekonomické změny doprovázející přechod od komunismu $\mathrm{k}$ postkomunismu dramaticky limitovaly možnosti jedinců. Podle Ceramiho (2008) se tedy také, stejně jako v zemích západní Evropy, objevuje rekomodifikace rizik, kdy zaměstnavatelé na nestabilitu práce, kapitálu a komodit odpovídají stále více tím, že přesunují tržní rizika na své zaměstnance. Úspěch jedinců je na soudobých trzích práce spojen $\mathrm{s}$ úspěšným převedením dovedností a pracovních schopností do zpeněžitelného zboží a služeb, které odpovídají poptávce na trzích.

21 Výjimkou byl rok 1999, kdy došlo k prudkému poklesu počtu rozvodů (23 657 v roce 1999), který byl způsoben změnou legislativy. „Od 1. srpna 1998 platí v České republice zákon č.91/1998 Sb., jenž změnil a doplnil zákon o rodině č. 94/1963 Sb., a tím podmínky pro rozvod upravil. Podmínkou rozvodu je mimo jiné to, že partneři žijí nejméně šest měsíců odděleně a oboustranný souhlas partnerů s podáním návrhu na rozvod. V praxi výši rozvodovosti nejvíce ovlivnilo ustanovení paragrafu 25 změněného zákona, jež určuje, že ,Manželství nelze rozvést, pokud nenabude právní moci rozhodnutí o úpravě poměrů nezletilých dětí pro dobu po rozvodu. 'Toto ustanovení podstatně komplikuje rozvodové řízení v rodinách s dětmi. Novelizace zákona rovněž neumožňuje rozvést manželství kratšího trvání než jeden rok.“ (ČSÚ 2002) 


\section{Reformy v zemích střední a východní Evropy}

Vládní reformy zemí střední a východní Evropy reagující na sociální rizika spojená s přechodem od centrálně plánované ekonomiky k tržní ekonomice a zároveň s posunem od industrialismu k postindustrialismu (tzv. dvojitá transformace, Strietska-Ilina 2001) se podle Ceramiho (2008) orientují především na a) privatizaci sociálních opatření, b) individualizaci rizik, c) monetarizaci př́ístupu k opatřením a d) decentralizaci řízení. Všechny tyto čtyři hlavní trendy probíhají ve formě znovuzavedení (nebo posílení) principu sociálního pojištění v celkovém systému sociálního zabezpečení, privatizace a diferenciace dávek v penzijním systému, zrušení Semashkova modelu zdravotní péče, ${ }^{22}$ spojené se zavedením decentralizovaného mixu veřejných/soukromých zařízení zdravotní péče, zavedení ochrany proti nezaměstnanosti skládající se z podpory v nezaměstnanosti a sociální podpory, redefinice směrem dolů od velmi štědrých dávek a nároků na ně poskytovaných $\mathrm{v}$ období komunismu v oblasti rodinných politik a zavedení nezbytné záchranné sítě pro nejchudší společenskou vrstvu (Cerami 2008). Dochází tak k posunu od universalistických opatření k opatřením podporujícím udrženi sociálního statusu, vedoucích ovšem také k růstu chudoby a príijmových nerovností (Cerami 2006, Barr 2005). Mezi další reformy sociálního státu zaměřené na specifická nová sociální rizika patří redukce opatření péče o děti a mateřských dovolených, ale zároveň s tím i zavedení rodičovské dovolené a prvních zákonů zaměřených na dlouhodobou péči, politiky aktivace a snahy o zavedení celoživotního i dalšiho vzděláváni (Cerami 2008).

Další reformy sociálních států střední a východní Evropy by pak měly vést k posílení adaptace jednotlivců na flexibilnější trhy práce a zvýšení jejich zaměstnatelnosti. Cerami (2008) v této souvislosti mluví o nové tzv. posilující (zplnomocňující) politice sociálního státu (the new empowering politics of the welfare state) se čtyřmi základními piliŕri:

a) garantovaný minimální př́ijem pro nejvíce ohrožené skupiny (posileni skrze dekomodifikaci) - zavedení systému minimálního př́ijmu se zdá být podle Ceramiho (2008) důležitým politickým nástrojem, který pomáhá chránit nejvíce ohrožené sociální skupiny prred chudobou a před př́jmovými nerovnostmi; na rozdíl od „starých politik sociálního státu“ hlavním cílem nesmí být jen zajištění příjmů pro osoby při dočasné ztrátě príijmů z trhu práce (strategie zmírnění chudoby), ale prioritním cílem by mělo být chránit jedince před riziky spojenými s deregulovanějšími, méně zajištěnými a redistributivními trhy práce;

b) základní příjem pro děti (posilení skrze investice do děti) - $\mathrm{s}$ cílem jednak ochránit děti před rostoucí chudobou (srovnej např. Esping-Andersen 2002), jednak umožnit rodičům věnovat více času jejich výchově i svému zaměstnání;

c) garantovaný, z daní financovaný důchod pro staré lidi propojený s konty odvislými od př́jmů (posileni skrze redistribuci životnich rizik) - základní penze, financovaná

22 Jednotný model uspořádání zdravotnických služeb, zavedený v zemích střední a východní Evropy po druhé světové válce a zrušený na počátku 90. let. Zdravotnictví bylo v tomto modelu financováno výhradně prostřednictvím státního rozpočtu, zdravotní péče se uskutečňovala výhradně ve veřejně vlastněných zdravotnických zařízeních. Různé úrovně státní správy (centrální, regionální a lokální) byly odpovědné za plánování, alokaci zdrojů a správu výdajů (European Observatory 2007). 
z daní a univerzálně dostupná dohromady s konty (soukromě ř́zenými) s odvody ze mzdy pro pracující;

d) veřejné investice do vzdělávání a formování lidského kapitálu (posílení skrze formováni lidského kapitálu) - opatření na zvýšení lidského kapitálu občanů skrze veřejné investice do vzdělávání a formování lidského kapitálu, užitečné pro jednotlivce, aby byli schopni zvládnout individualizaci a monetarizaci rizik efektivnějším způsobem a byli adaptabilnější a zaměstnatelnější; tato opatření jsou však užitečná také pro formování nových znalostí a dovedností vhodnějších pro soudobé, na znalostech založené ekonomiky, tedy investice posilující konkurenceschopnost a rozvoj dané ekonomiky - naprríklad poskytováním vzdělávání a tréninku v těch sektorech ekonomiky, kde jsou soukromé investice př́liš nákladné a méně výnosné pomáhají veřejné politiky zaměstnavatelům najít adekvátně vyškolenou pracovní sílu na trhu práce a zvyšují tak konkurenceschopnost národní ekonomiky (Cerami 2008).

Sociální politika v soudobé společnosti by tedy podle autorů již neměla být nadále chápaná jako prrítěž pro ekonomický rozvoj, ale spíše jako investice pro vylepšení adaptability a zvýšení zaměstnatelnosti pracovní síly na trhu práce (Estevez-Abe, Iversen, Soskice 2001, Hall, Soskice 2001, Pierson 2001, Taylor-Gooby 2005, Cerami 2008 aj.).

Sociální politiky navíc hrají důležitou funkci institucionálních komplementarit (Hall, Soskice 2001, Estevez-Abe, Iversen, Soskice 2001 aj.). Podle tohoto teoretického konceptu instituce v jednom typu tržní ekonomiky by navzájem měly posilovat jedna druhou. Typickým př́kladem institucionálních komplementarit, diskutovaným hojně v literatuře (EstevezAbe, Iversen, Soskice 2001, Ebbinghaus, Manow 2001, Iversen, Stephens 2008, Edlund, Grönlund 2008 aj.), je vztah mezi systémem dalšího odborného vzdělávání (spojený s typem produkčního režimu), ochranou v nezaměstnanosti a ochranou pracovního místa. Podle konceptu institucionálních komplementarit jsou pracovníci ochotni investovat do specifické kvalifikace pouze za předpokladu, že se jim tato investice v dlouhodobé perspektivě vrátí. Pokud nejsou znalosti a dovednosti firemně specifické a jsou na trhu práce poptávány, pracovníci mohou předpokládat, že v př́padě ztráty zaměstnání najdou práci v jiné firmě. V případě investice do firemně specifických znalostí a dovedností však pracovníci očekávají bud' dlouhodobý pracovní poměr, a/nebo externí jistoty. Silná ochrana pracovního místa a kolektivní smlouvy tak mohou pracovníky přesvědčit k investicím do firemně specifických znalostí a dovedností tím, že jim poskytují jakousi jistotu, že si zaměstnání a výši mzdy udrží i v době horší ekonomické situace firmy. A pokud už by byli propuštěni, očekávají, že získají podporu na dobu dostatečně dlouhou na to, aby si našli jiné zaměstnání odpovídající jejich kvalifikaci, př́padně očekávají, že obdrží veřejné subvence pro potřebnou změnu své kvalifikace. Instituce ochrany pracovního místa a ochrana $\mathrm{v}$ nezaměstnanosti tak podporují investice do specifických znalostí a dovedností a pomáhají formovat a rozvíjet specifický typ lidského kapitálu.

Nová paradigmata objevující se v sociální politice vlivem změn ekonomických, demografických i společenských (Taylor-Gooby 2005, Pierson 2001, Cerami 2008 aj.) tak jasně reorientují cíle sociálních politik a restrukturují výdaje sociálních států směrem k politikám nových sociálních rizik, tedy mj. k posílení zaméstnatelnosti, adaptability a flexibility pracovní síly za pomoci nástroju aktivní politiky zaměstnanosti a celoživotním vzděláváním. Sociální politiky tak pomáhají mobilizovat pracovní sílu, zvyšují konkurenceschopnost a podporují 
komparativní výhody národních ekonomik. Plní tak i důležitou funkci institucionálních komplementarit, kdy by měly posilovat funkce a efektivitu dalších institucí (Hall, Soskice 2001), jako je např́íklad flexibilita na trzích práce, systém počátečního i dalš́ho vzdělávání aj.

\section{Závěr}

Nová sociální rizika vymezená autory, jako je Esping-Andersen, Taylor-Gooby či Armingeon, Bonoli, na základě analýz socio-ekonomických změn v zemích západní Evropy se jen částečně překrývají s formami nových sociálních rizik objevujících se v postkomunistických zemích střední a východní Evropy. V těchto zemích totiž došlo (a v některých případech stále postupně dochází) souběžně $\mathrm{k}$ tzv. dvojí transformaci - nejen k posunu od industrialismu k postindustrialismu, ale zároveň i $\mathrm{k}$ přechodu od centrálně plánované ekonomiky k tržní ekonomice. ${ }^{23}$ To s sebou nese radikální proměnu sociálních rizik. Kromě nových sociálních rizik identifikovaných Armingeonem a Bonolim (2006) a Taylorem-Goobym (2004a, 2005) - jakými jsou především ohrožení rovnováhy mezi pracovní kariérou a rodinnými povinnostmi, riziko rychlého zastarávání kvalifikace a s tím spojené riziko udržení si adekvátně placeného zaměstnání a mzdového zajištění v podmínkách rychle se proměňujících požadavků na trhu práce, riziko zapř́íciněné využíváním privátních sociálních systémů, riziko nedostatečného pokrytí sociálním zabezpečením v období nezaměstnanosti, nemoci, invalidity či stáŕí v důsledku atypických (přerušovaných) pracovních kariér - se sociální státy zemí stř̌ední a východní Evropy musejí vyrovnat i s takovými problémy, jako jsou nejistý př́istup k penzím, zdravotní péči, zaměstnání, nezbytnému př́ijmu, rodinným politikám i vzdělávacím příležitostem (Cerami 2008).

Nicméně obecné reformní trendy sociálních států v reakci na nově se objevující sociální rizika jsou v zemích západní Evropy i zemích střední a východní Evropy obdobné. Důraz je kladen především na posílení konkurenceschopnosti a zaměstnatelnosti a rozšíření př́iležitostí např́íklad formami celoživotního vzdělávání (další odborné vzdělávání, rekvalifikace, školení atp.), nástroji aktivní politiky zaměstnanosti, ale třeba i socializací pečovatelských služeb pro usnadnění harmonizace práce a rodinného života. Zároveň dochází k posilení principu vlastní odpovědnosti za sociální blaho, $\mathrm{k}$ individualizaci sociálních rizik a zapojení dalších sociálních aktérů (především zaměstnavatelů) do řešení problémů s nimi spojených.

Reformy směrují $\mathrm{k}$ tomu, aby sociální politika byla brána jako komplementární $\mathrm{k}$ cílům ekonomického růstu a rozvoje, ne jako jejich bariéra. Primárními cíli se stávají mobilizace pracovní síly (pomocí nástrojů aktivní politiky zaměstnanosti i různých forem celoživotního vzdělávání), zvýšení produktivity a posílení ekonomického růstu a zároveň vylepšení situace znevýhodněných skupin (osamělých rodičů, nízko- a nekvalifikovaných pracovníků atd.) a snížení chudoby (viz posilující politika sociálního státu, Cerami 2008).

Ač se konkrétní opatření $\mathrm{v}$ reakci na nově se objevující sociální rizika $\mathrm{v}$ různých zemích liší (strategie jsou podmíněné stávajícími systémy sociálního zabezpečení - režimová

23 Samozřejmě lze hovořit i o dalších dimenzích transformace zemí střední a východní Evropy (např. občanská transformace, institucionalizace demokratické politiky aj.), nicméně pro tuto práci jsou relevantní zejména dvě výše zmíněné dimenze. 
specifičnost, „path-dependency“, ale i načasováním socioekonomického vývoje té které země), výše popsané cíle a priority se zdají být obecnými vodítky stávajících reforem sociálních států v celé Evropě.

\section{Literatura}

ARMINGEON, Klaus ; BONOLI, Giuliano. (eds.). The Politics of Post-Industrial Welfare States. Adapting Post-War Social Policies to New Social Risks. 1. vyd. New York : Routledge, 2006. 272 s. ISBN 0-41538-072-3.

BARR, Nikolas A. From transition to accession. In BARR, N.A. (ed.) Labor Market and Social Policy in Central and Eastern Europe : the Accession and Beyond. Washington : World Bank, 2005, s. 1 - 30. ISBN 0-82136-119-8.

BONOLI, Giuliano. Adapting Employment Policies to Post-Industrial Labour Market Risks Working. Paper de l'IDHEAP [online]. 2006, č. 6. [cit. 18. 3. 2008]. Dostupné na www: http://www-idheap. unil.ch/idheap.nsf/ed6f7e242e9019a7c12569ff0038e8f9/487d91da132f2231c12571730050c524/ \$FILE/texte\%20wp\%206-2006\%20Bonoli.pdf.

BONOLI, Giuliano. New Social Risks and the Politics of Post-Industrial Social Policies. In ARMINGEON, K., BONOLI, G. (eds.). The Politics of Post-Industrial Welfare States. Adapting post-war social policies to new social risks. 1. vyd. New York : Routledge2006, s. 3 - 26. ISBN 0-41538-072-3.

BONOLI, Giuliano. Time Matters. Postindustrialization, New Social Risks, and Welfare State Adaptation in Advanced Industrial Democracies. Comparative Political Studies, 2007, roč. 40, č. 5, s. 495 - 520. ISSN 0010-4140.

CERAMI, Alfio. New Social Policy Ideas in the Making : The Case of Central and Eastern Europe. Paper presented at the conference Transformation of the Welfare State: Political Regulation and Social Inequality. 4th Annual ESPAnet Conference, 21-23 September 2006. University of Bremen, Germany, 2006.

CERAMI, Alfio. Social Policy in Central and Eastern Europe. The Emergence of a New European Welfare Regime. Berlin : LIT Verlag, 2006. 272 s. ISBN 3-8258-9699-4.

CERAMI, Alfio. New Social Risks in Central and Eastern Europe : The Need for a New Empowering Politics of Welfare State. Czech Sociological Review, 2008, roč. 44, č. 6, s. 1089 - 1100. ISSN 0038-0288.

ČSÚ. Vývoj sn̆atečnosti a rozvodovosti v ČR po roce 1989. [online]. 2002. [cit. 31. 5. 2009]. Dostupné na www: <http://www.czso.cz/csu/2002edicniplan.nsf/p/1112-02>.

ČSÚ. Demografická ročenka krajů 1998 až 2007. [online]. 2008. [cit. 31. 5. 2009]. Dostupné na www: $<$ http://www.czso.cz/csu/2008edicniplan.nsf/p/4027-08 >.

ČSÚ. Trh práce v $\check{C} R 1993$ až 2007. [online]. 2008. [cit. 20. 5. 2009]. Dostupné na www: <http://www. czso.cz/csu/2008edicniplan.nsf/p/3103-08>.

EBBINGHAUS, Bernhard ; MANOW, Philip (eds.). Comparing Welfare Capitalism : Social policy and political economy in Europe, Japan and the USA. London, New York : Routledge, 2001. 323 s. ISBN 0-41525-571-6.

EC. What is Flexicurity? [online]. 2008. [cit. 27. 4. 2008]. Dostupné na www: <http://ec.europa.eu/ employment_social/employment_strategy/flex_meaning_en.htm>.

EDLUND, Jonas ; GRÖNLUND, Anne. Protection of Mutual Interests? Employment Protection and Skill Formation in Different Labour Market Regimes. European Journal of Industrial Relations, 2008, roč. 14, č. 3. s. 245 - 264. ISSN 1461-7129. 
ELLISON, Nick. The Transformation of Welfare State? London : Routledge, 2006. 223 s. ISBN 0-415-14250-4.

ESPING-ANDERSEN, Gøsta. The Three Worlds of Welfare Capitalism. New Jersey : Princenton University Press, 1990. 248 s. ISBN 0-69109-457-8.

ESPING-ANDERSEN, Gøsta. Social Foundations of Postindustrial Economies. Oxford : Oxford University Press, 1999. 224 s. ISBN 0-19874-200-2.

ESPING-ANDERSEN, Gøsta. Why We Need a New Welfare State. Oxford : Oxford University Press, 2002. 228 s. ISBN 978-0-19925-642-6.

ESTEVEZ-ABE, Margarita; IVERSEN, Torben ; SOSKICE, David. Social Protection and the Formation of Skills : A Reinterpretation of the Welfare State. In HALL, P., SOSKICE, D. Varieties of Capitalism : The Institutional Foundations of Comparative Advantage. New York : Oxford University Press, 2001. s. 145 - 183. ISBN 0-19-924774-9.

European Observatory. Glossary-Semashko system. [online.]. 2007. [cit. 1. 6. 2009.] Dostupné na www: $<$ http://www.euro.who.int/observatory/Glossary/TopPage?phrase=Semashko\%20system>.

HALL, Peter ; SOSKICE, David. An Introduction to Varieties of Capitalism. In HALL, P., SOSKICE, D. Varieties of Capitalism : The Institutional Foundations of Comparative Advantage. New York : Oxford University Press, 2001. s. 1 - 68. ISBN 0-19924-775-7.

HALL, Peter ; SOSKICE, David. (eds.). Varieties of Capitalism : The Institutional Foundations of Comparative Advantage. New York: Oxford University Press, 2001. 560 s. ISBN 0-19924-775-7.

HUBER, Evelyn; STEPHENS, John D. Combating Old and New Social Risks. In ARMINGEON, K., BONOLI, G (eds.). The Politics of Post-Industrial Welfare States. Adapting Post-War Social Policies to New Social Risks. 1. vyd. New York : Routledge, 2006. s. 143 - 168. ISBN 0-41538-072-3.

IVERSEN, Torben; STEPHENS, John D. Capital Formation Partisan Politics, the Welfare State, and Three Worlds of Human. Comparative Political Studies, 2008, roč. 41, č. 4/5, s. 600 - 637. ISSN 0010-4140.

JAEGER, Mads M. ; KVIST, Jon. Pressures on State Welfare in Post-Industrial Societies: Is More or Less Berger? Social Policy \& Administration, 2003, roč. 37, č. 6, s. 555 - 572. ISSN 0144-5596.

KLIMPLOVÁ, Lenka. Nezaměstnanost v České republice 1991-2000. Brno : FSS MU, 2001. [Bakalářská diplomová práce].

KLIMPLOVÁ, Lenka. Od industrialismu k postindustrialismu v západních zemích-od starých k novým sociálním rizikům. Sociálne a politické analýzy, 2008, roč. 2, č. 2, s. 1 -39. ISSN 1337-5555.

KLIMPLOVÁ, Lenka. Lidský kapitál a faktory vyvolávající změny v nárocích na něj na soudobých trzích práce. Scientia et Societas, 2010, roč. 6, č. 1. ISSN 1801-7118. [v tisku].

KUBÁTOVÁ, Jaroslava. Význam lidského kapitálu v postindustriální společnosti. Politologica, Acta Universitatis Palackianae Olomucensis, 2004, č. 3, s. 9 - 28. ISSN 1214-3251.

MAlBerG, Bo. [et al]. Global Population Ageing, Migration and European External Policies. [online.] 2006. European Comission. Stockholm : Institute for Future Studies. [cit. 11. 4. 2008]. Dostupné na www: <http://ec.europa.eu/employment_social/spsi/docs/social_situation/walter_ migration_fin_rep_en.pdf $>$.

MISHRA, Ramesh. Globalization and the Welfare State. Cheltenham : Edward Edgar, 1999. $121 \mathrm{s.}$ ISBN 1-84064-173-8.

OECD. OECD Family Database. [online]. 2008. [cit.1. 6. 2009.] Dostupné na www: <http://www.oecd. org/document/4/0,3343,en_2649_34819_37836996_1_1_1_1,00.html>.

PIERSON, Paul. Dismantling the Welfare State? Reagan, Thatcher, and the Politics of Retrenchment. Cambridge : Cambridge University Press, 1994. 224 s. ISBN 0-52155-570-1.

PIERSON, Paul (ed.). The New Politics of the Welfare State. Oxford : Oxford University Press, 2001. 528 s. ISBN 0-19829-756-4. 
PIERSON, Paul. Post-Industrial Pressures on the Mature Welfare State. In PIERSON, P. (ed.): The New Politics of the Welfare State. Oxford : Oxford University Press, 2001, s. 80 - 104. ISBN 0-19829-756-4.

PIERSON, Paul. Coping with Permanent Austerity : Welfare State Restructuring in Affluent Democracies. In PIERSON, P. (ed.) The New Politics of the Welfare State. Oxford : Oxford University Press, 2001, s. 410 - 456. ISBN 0-19829-756-4.

PIERSON, Paul. Politics in Time : History, Institutions, and Social Analysis. Princenton : Princenton University Press, 2004. 208 s. ISBN 0-69111-715-2.

RINGOLD, Dena. The course of transition. In BARR, N. (ed.) Labor Market and Social Policy in Central and Eastern Europe: the Accession and Beyond. Washington: World Bank, 2005, s. 31 - 57. ISBN 0-82136-119-8.

SCHARPF, Fritz W. ; SCHMIDT, Vivien A. (eds.) Welfare and Work in the Open Economy. Volume I. From Vulnerability to Competitivness. Oxford : Oxford University Press, 2000. 424 s. ISBN 0-19924-088-4.

SCHARPF, Fritz W. ; SCHMIDT, Vivien A. (eds.) Welfare and Work in the Open Economy. Volume II. Diverse Responses to Common Challenges in Twelve Countries. Oxford : Oxford University Press, 2000. 680 s. ISBN 0-19924-092-2.

Schienstock, Gerd ; Bechmann, Gotthard ; Frederichs, Günther. Information Society, Work and the Generation of New Forms of Social Exclusion (SOWING)-the Theoretical Approach. [online]. 1999.TA-Datenbank-Nachrichten, č. 1, 8. s. 3 - 49. [cit. 29. 5. 2009]. Dostupné na www: <http:// www.itas.fzk.de/deu/tadn/tadn991/scua99a.htm>.

Strietska-Ilina, Olga. Research on vocational education and training at the crossroads of transition in Central and Eastern Europe. In DESCY, P., TESSARING, M. (eds.) Training in Europe. Second report on vocational training research in Europe 2000: background report. Volume 3. Cedefop Reference series. Luxembourg : European Communities, 2001. s. 209 - 318. ISBN 92-896-0086-1.

TAYLOR-GOOBY, Peter. (ed.) New Risks, New Welfare. The Transformation of the European Welfare State. Oxford : Oxford University Press, 2004. 268 s. ISBN 978-0-19-926726-2.

TAYLOR-GOOBY, Peter. New Risks and Social Change. In TAYLOR-GOOBY, P. (ed.) New Risks, New Welfare. The Transformation of the European Welfare State. Oxford : Oxford University Press, 2004. s. 1 - 28. ISBN 978-0-19-926726-2.

TAYLOR-GOOBY, Peter. New Social Risks and Welfare States : New Paradigma and New Politics? In TAYLOR-GOOBY, P. (ed.) New Risks, New Welfare. The Transformation of the European Welfare State. Oxford : Oxford University Press, 2004. s. 209 - 238. ISBN 978-0-19-926726-2.

TAYLOR-GOOBY, Peter. New Social Risks in Postindustrial Society : Some Evidence on Response to Active Labour Market Policies from Eurobarometer. International Social Security Review, 2004, roč. 57, č. 3, s. $45-64$. ISSN 1468-246X.

TAYLOR-GOOBY, Peter. (ed.) Making a European Welfare State? Convergences and Conflicts Over European Social Policy. Oxford : Blackwell Publishing, 2004. 288 s. ISBN 1-40512-116-5.

TAYLOR-GOOBY, Peter. (ed.) Welfare Reform and the Management of Societal Change. Final report. [online]. 2005, [cit. 23. 3. 2008]. Dostupné na www: <http://www.kent.ac.uk/wramsoc/eureports/ informationforeureports/finalreport/finalreport.pdf>.

TIMONEN, Virpi. Earning Welfare Citizenship : Welfare State Reform in Finland and Sweden. In TAYLOR-GOOBY, P. (ed.) Welfare States Under Pressure. 1. vyd. London : Sage Publications, 2001, s. 29 - 51. ISBN 076197198X.

TIMONEN, Virpi. Restructuring the Welfare State. Globalization and Social Policy Reform in Finland and Sweden. Cheltenham : Edward Edgar. 2003. 232 s. ISBN 1843761246.

WREN, Anne. The Challenge of De-Industrialization : Divergent Ideological Response to Welfare State Reform. In EBBINGHAUS, B., MANOW, P. (eds.) Comparing Welfare Capitalism : Social Policy 
and Political Economy in Europe, Japan and the USA. London, New York : Routledge, 2001. s. 239 - 269. ISBN 0-41525-571-6.

\section{Autorka}

je postgraduální studentkou na katedře SPSP FSS MU v Brně. Zabývá se tématem nových sociálních rizik a rolí zaměstnavatelů. Podílí se na výzkumném projektu „Nová sociální rizika trhu práce a potřeby reformy jeho politické regulace po vstupu ČR do EU (monitoring a vyhodnocení potřeb)“،.

Kontakt: klimplov@fss.muni.cz 